\title{
Introducere în metaanaliză. Metaanaliza corelațiilor
}

\author{
Laurențiu P. Maricuțoiu ${ }^{1}$ \\ Universitatea de Vest din Timișoara
}

\begin{abstract}
The present paper discusses the fundamental principles of meta-analysis, as a statistical method for summarising results of correlational studies. We approach fundamental issues such as: the finality of meta-analysis and the problems associated with study artefacts. The paper also contains recommendations for: selecting the studies for meta-analysis, identifying the relevant information within these studies, computing mean effect sizes, confidence intervals and heterogeneity indexes of the mean effect size. Finally, we present indications for reporting meta-analysis results.
\end{abstract}

Key words: meta-analysis, correlations, statistical methods

\section{Résumé}

Cet article pressente les principes fondamentales du meta-analyse, un méthode statistique de rassembler et de réanalyser les résultats d'études comparables qui ont utiliser la corrélation. L'article pressente problèmes fondamentaux dans l'étude meta-analytique : la finalité de cette type d'étude et les problèmes associe avec les artefacts de la recherche sociale. Nous pressentons des recommandations pour: la sélection d'études pour la meta-analyse, l'identification des information relevante contenu dans les études analyse, la moyenne de calcul de la magnitude d'effets, les confiance intervalles et les indices l'hétérogénéité des résultats des études individuelles. Finalement, on pressente les standards de rapporter les résultats obtenus dans la meta-analyse.

Mots-clés: meta-analyse, corrélation, méthodes statistiques

\section{Introducere}

Metaanaliza este 0 metodă care „permite revizuirea unui domeniu de cercetare şi determinarea gradului în care un rezultat particular a fost replicat cu succes de diverse cercetări” (Eden 2002, p.841). Deşi dezvoltarea acestei metode nu a fost lipsită de critici, metaanaliza s-a impus ca tehnică de analiză cantitativă a rezultatelor obținute de studiile derulate într-un anumit domeniu de cercetare.

În România, metaanaliza este încă la început. În ciuda prezentării principiilor metodei în capitole precum „Metaanaliza” (Miclea, 1994) sau „Metaanaliza şi validitatea generalizată" (Hohn, Vârgă \& Măruşter, 1999), marea majoritate a psihologilor nu au decât cel mult cunoştințe generale legate de această metodă. De exemplu, în cadrul Conferințor Naționale de Psihologie au fost prezentate două astfel de studii în 2008 (Rusu, Macavei,

\footnotetext{
${ }^{1}$ Adresa de contact: Imaricutoiu@socio.uvt.ro
}

Moldovan \& Pintea, 2008; Popa, Negoescu, Pleşea \& Maricuțoiu, 2008) şi doar unul în 2006 (Trip, 2006).

Articolul de față se doreşte a fi o introducere în tehnica metaanalizei corelațiilor. Vom prezenta principalele elemente metodologice prezente în orice demers metaanalitic, precum şi etapele ce trebuie urmate în planificarea şi derularea unui astfel de demers.

\section{Problema comparării studiilor}

Problema principală a metaanalizei este de a transforma rezultatele statistice obținute în studii cu design experimental diferit în indicatori comuni, care să poată fi comparați. De exemplu, cum putem compara rezultatele obținute într-un experiment în care $\mathrm{s}$-a recurs la 2 măsurători repetate $\mathrm{cu}$ rezultatele obținute într-un experiment cu 3 eşantioane independente? Cum putem compara un coeficient de corelație obținut în urma aplicării testelor la 60 de subiecți cu un 
coeficient de corelație obținut în urma aplicării aceloraşi teste la 160 de subiecți?

Pentru a rezolva această problemă, rezultatele raportate de studii sunt transformate într-o măsură a eficienței relațiilor identificate care să nu fie dependentă de pragul de semnificație înregistrat, iar această măsură este numită mărimea efectului (Durlak, 2005; Sava, 2004; Sava \& Maricuțoiu, 2007).

Mărimea efectului ar trebui raportată în orice cercetare, atât pentru a arăta importanța practică a rezultatului obținut cât şi pentru a facilita includerea acestor rezultate în metaanalize. Totuşi, raportarea mărimii efectului nu este o practică curentă, ceea ce obligă autorii metaanalizelor să calculeze aceşti indicatori pentru fiecare studiu în parte. Calcularea mărimii efectului poate fi realizată atât manual cât şi utilizând software-uri specializate în acest sens (G-Power - Faul \& Erdfelder, 1992; Power and Precision Borestein, Rothstein \& Cohen, 2001; PowerStaTim - Maricuțoiu \& Sava, 2007).

\section{Finalitatea metaanalizei}

Scopul metaanalizei este de a ajunge la un „super-rezultat” care să descrie intensitatea fenomenului studiat la nivelul populației generale (de Leeuw \& Hox, 2003).

Acest „super-rezultat” este compus din trei elemente: o medie a mărimii efectelor înregistrate de studiile introduse în metaanaliză, un interval de încredere al acestei medii şi o estimare a omogenității rezultatelor analizate. Astfel, „super-rezultatul” ideal este caracterizat de un efect mediu puternic, un interval de încredere care nu se apropie sau nu include valoarea "0" şi un indice de omogenitate cât mai ridicat.

Omogenitatea rezultatelor nu se referă la utilizarea aceleiaşi metode statistice, ci la o varianță moderată a pragurilor de semnificație sau a indicatorilor de mărime a efectului. Cu alte cuvinte, dacă rezultatele nu diferă în urma artefactelor studiilor în mai mare măsură decât este de aşteptat, ele sunt considerate a fi omogene (Hox, 1995, p.67). Heterogenitatea rezultatelor analizate este o surpriză oarecum neplăcută pentru cercetătorul care realizează o metaanaliză deoarece această situație indică faptul că studiile analizate raportează variații mult prea mari pentru a se trage o concluzie general valabilă.

\section{Tipuri de metaanaliză}

Problema diferențelor dintre rezultatele diferitelor studii a fost abordată în mod diferit de-a lungul timpului. Schimdt şi Hunter (2003, p. 544) analizează retrospectiv aceste abordări, împărțindu-le în patru mari categorii: metaanalize descriptive, metaanalize care analizează eroarea de eşantionare, metaanalize în care sunt eliminate influențele artefactelor de cercetare şi metaanalizele psihometrice.

Metaanalize pur descriptive se limitează la cuantificarea mărimii efectului pentru studii diferite şi a variației acesteia. Această perspectivă afirmă că variația mărimii efectului este normală şi poate fi explicată prin calcularea corelațiilor dintre caracteristicile studiilor şi mărimea efectului înregistrată de acestea. Un astfel de demers ridică însă mai multe probleme: cum înregistrăm caracteristicile studiilor, dacă putem înregistra aceste caracteristici pentru toate studiile şi, nu în ultimul rând, ce se întâmplă dacă aceste caracteristici nu corelează cu mărimea efectului. În plus, această abordare nu este interesată de calcularea indicelui de omogenitate despre care aminteam în rândurile anterioare.

Metaanalizele care analizează eroarea de eşantionare pleacă de la constatarea faptului că cel mai important aspect care produce variația mărimii efectului este eroarea de eşantionare. Există două mari metode de analiză a erorii de eşantionare: metaanaliza "oaselor goale" (bare-bones meta-analysis) propusă de Hunter şi Schmidt (2004) şi metaanaliza axată pe testarea heterogenității studiilor (Rosenthal, Jhoyt, Ferrin, Miller \& Cohen, 2006; Rosenthal \& DiMatteo 2001). Diferența dintre aceste două perspective constă în faptul că în metaanaliza „oaselor goale" se calculează un coeficient de omogenitate, pe când în cealaltă variantă se calculează un coeficient de eterogenitate (testul Q). Aceste două abordări duc de obicei la rezultate relativ similare.

Metaanaliza artefactelor analizează atât eroarea de eşantionare cât şi erorile de măsurare. Termenul de artefact de cercetare este utilizat în literatura de specialitate pentru a desemna acea caracteristică a studiului care poate duce la influențarea rezultatelor obținute (Hunter \& Schmidt, 2004). Această categorie de metaanalize reprezintă o dezvoltare a metaanalizei „oaselor goale" prin ajustarea rezultatelor individuale ale studiilor în scopul eliminării influențelor artefactelor. 
Metaanalizele psihometrice sunt cele mai avansate, încercând să identifice variabilele moderatoare care duc la apariția unor rezultate eterogene. În literatura de specialitate, acestea sunt relativ rare deoarece în marea majoritate a cazurilor rezultatele sunt omogene, ceea ce nu justifică utilizarea acestor tehnici. În plus, deoarece metaanalizele psihometrice solicită un număr mare de rezultate (şi implicit de studii analizate), foarte puține demersuri metaanalitice au posibilitatea aplicării lor.

\section{Variația rezultatelor studiilor. Problematica artefactelor de cercetare}

$\mathrm{Ca}$ demers statistic, metaanaliza pleacă de la constatarea diferențelor între rezultatele obținute de studii diferite. După cum am afirmat anterior, termenul de artefact de cercetare se referă la acea caracteristică a studiului care poate influența rezultatele obținute.

Totuşi, nu toate artefactele de cercetare acționează în acelaşi fel. Hunter şi Schmidt (2004) afirmă că erorile care duc la obținerea unor rezultate diferite pot fi aleatoare sau sistematice. Principala diferență dintre aceste două tipuri de erori constă în faptul că erorile sistematice pot fi corectate iar erorile aleatoare pot fi doar diagnosticate.

Unul dintre cele mai importante artefacte de cercetare este eroarea de eşantionare: cercetările ajung la rezultate diferite deoarece nu au fost derulate pe întreaga populație, ci pe eşantioane extrase din aceasta prin metode aleatoare sau nealeatoare (Huffcutt, 2007). Datorită tehnicilor de eşantionare utilizate, rezultatele unui studiu vor fi diferite de un rezultatul "real” de la nivelul populației, ajungându-se astfel în situația de a avea rezultate variate de la un studiu la altul chiar dacă acestea sunt derulate pe aceeaşi populație. Pentru a determina gradul în care eroarea de eşantionare influențează diferențele dintre studii, cercetătorii apelează la metaanaliza „oaselor goale" (bare-bones meta-analysis) propusă de Hunter şi Schmidt (2004) şi metaanaliza axată pe testarea heterogenității studiilor (Rosenthal, Jhoyt, Ferrin, Miller \& Cohen, 2006; Rosenthal \& DiMatteo 2001).

Totuşi, tehnica eşantionării nu este singurul element responsabil pentru rezultatele diferite obținute în cercetare. Hunter şi Schimdt (2004) explică mai multe surse posibile ale diferențelor dintre studii. Deşi autorii citați anterior enumeră 11 astfel de artefacte, am preferat gruparea lor în 6 clase, pentru a evita repetiția explicațiilor (de exemplu, Hunter şi Schmidt mentionează eroarea de măsurare a VI sau VD ca reprezentând două artefacte diferite, oferind aceeaşi explicație asupra efectului acestora asupra rezultatelor studiului).

\section{Eroarea de măsurare a variabilei dependente sau independente}

Validitatea studiului va fi în mod sistematic mai scăzută decât validitatea reală datorită faptului că măsurarea variabilelor studiului nu este perfectă. În mod tradițional, psihologii utilizează coeficienți ai consistenței interne, ca modalitate de a verifica fidelitatea instrumentelor pe care le utilizează (Cronbach \& Shavelson, 2004).

În teoria item-test, răspunsul fiecărui individ la un test este rezultatul sumei dintre scorul real al subiectului şi eroarea de măsurare a instrumentului (Stan, 2002 p.141). Coeficientul alfa al lui Cronbach nu este nimic altceva decât pătratul corelației dintre scorurile reale şi cele măsurate (Cronbach \& Shavelson, 2004, p. 400). În Figura 1, valoarea lui alfa Cronbach este reprezentată de suprafața de interacțiune dintre scorul real şi cel măsurat (marcată cu litera B). Suprafața „A" reprezintă acel aspect al variabilei de interes care nu este măsurat de instrument, iar eroarea de măsurare este reprezentată de suprafața marcată cu „er”.

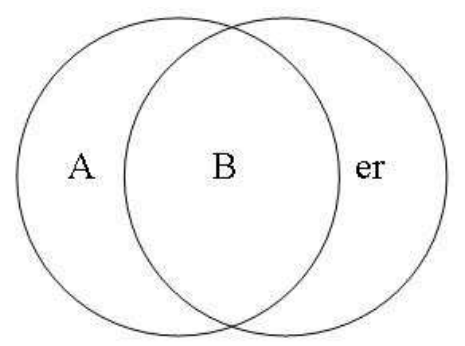

Figura 1. Relația dintre scorul real şi cel măsurat

Problema este că în situația în care dorim să corelăm două variabile, coeficientul de corelație obținut în urma măsurătorii va fi mai scăzut decât cel real. Să presupunem că avem două variabile de interes $(X$ şi $Y)$, fiecare cu consistențe interne considerate bune $(\alpha=$ .80). Această consistență internă ne indică faptul că $20 \%$ din varianța scorului real al lui $X$ şi $Y$ nu este măsurată de instrumentele utilizate de cercetător. În acelaşi timp, un 
procent egal (20\%) din varianța scorului obținut de subiecți nu are nici o legătură cu variabila psihologică pe care dorim să o măsurăm. În aceste condiții, coeficientul de corelație obținut de cercetător ne va indica dispersia comună a ceea ce măsurăm din fiecare variabilă şi nu asocierea reală dintre acestea două.

Un aspect important de care metaanaliza trebuie să țină cont este faptul că fidelitatea testelor psihologice nu este general valabilă. Coeficientul alfa (Cronbach) este un indicator al fidelității specific grupului pe care a fost calculat, iar valoarea lui poate varia în funcție de compoziția grupului testat şi caracteristicile situaționale ale testării (Urbina 2004, p.120).

\section{Dihotomizarea unei variabile continue}

Practica cercetătorilor de a împărți populația în categorii pe baza unei variabile continue (de exemplu: scăzut vs. ridicat) se va reflecta în rezultatele studiului.

Această eroare apare datorită nerespectării algoritmului de formare a grupelor contrastante (pentru mai multe detalii, vezi Albu, 1998, p.30-35) şi datorită faptului că gruparea se face pe baza unei variabile psihologice, deci pe baza unor scoruri măsurate nu pe baza unor scoruri reale.

Variabila independentă (predictorul) este de tip discret daca ea a fost măsurată de la început pe o scală de tip nominal. lată câteva exemple de situații în care împărțirea subiecților în cele două grupe are la bază o variabilă de tip discret (Sava \& Maricuțoiu, 2007):

- diferențe între bărbați şi femei;

- diferențe între grupul experimental şi grupul de control;

- diferențe între două clase de elevi paralele;

- diferențe între două grupe infracționale: hoți vs. criminali etc.

Situația în care variabila independentă (predictorul) a fost inițial măsurată pe o scala numerică, iar ulterior, pe baza rezultatelor obținute, subiecții sunt împărțiți în două grupe de subiecți este tipică pentru cazul variabilelor de tip continuu care au fost dihotomizate. lată câteva exemple din această situație (Sava \& Maricuțoiu, 2007):

- diferența dintre cei admişi şi cei respinşi la examenul de admitere (inițial aceştia aveau note cuprinse între 1 şi 10, dar au fost ulterior împărțtiti în două grupe: cei având media sub 5 vs. cei cu media 5 şi peste 5 (de trecere);

- diferența dintre introvetiți şi extrovertiți cu privire la performantele lor în vânzări, împărțirea în cele două categorii având la bază includerea în categoria introvertiților pe cei care obțin performanțe sub medie la scala de extroversiune şi includerea în categoria extravertititior pe cei care obțin performanțe peste medie la scala de extroversiune;

- diferența între cei cu performanță ridicată (peste valoarea medianei) şi cei cu performanță scazută (sub valoarea medianei), performanța fiind măsurată numeric în numărul de răspunsuri corecte la un test de cunostințe.

În cazul împărțiii subiecților pe baza unei variabile de tip continuu, subiecții dintr-o grupă sunt uneori mai eterogeni între ei decât subiecții din cealaltă grupă. De pildă, o persoană din grupa "admis" având media 5,03 este introdusă în aceeaşi grupă cu 0 altă persoană admisă cu media 9.24 , în timp ce o altă persoană, cu media 4,98 face parte din grupa "respinşi", deşi diferența este doar de 5 sutimi față de prima persoană. De aceea, unii cercetători recomandă evitarea dihotomizării variabilei continue, preferând alte tehnici statistice, cum ar fi regresia liniară.

\section{Amplitudinea specifică eşantionului studiat}

Acest artefact se referă la faptul că, prin eşantionare, amplitudinea scorurilor subiecților investigați va fi mai mică sau mai mare decât cea a populației generale. De exemplu, studiile pe inteligență sunt derulate pe eşantioane de conveniență, ceea ce face ca amplitudinea acestei variabile la nivelul eşantionului studiat să fie mai mică decât amplitudinea populației, în sensul că din eşantionul respectiv vor lipsi subiecți cu scoruri foarte scăzute sau foarte ridicate la variabila inteligență. În această situație, rezultatele raportate vor fi valabile doar pentru segmentul de populație investigat şi nu pentru populația generală.

Devierea de la o validitate perfectă de construct, în cazul variabilelor măsurate

Structura factorială a unei scale este determinată de patternul de corelații dintre 
itemii respectivei scale. Acest pattern de corelații poate varia de la o populație la alta şi poate duce la structurarea itemilor pe un număr diferit de factori față de modelul inițial al instrumentului. Aplicarea instrumentelor de măsurarea fără validarea lor factorială (Albu, 1998) poate duce astfel la modificarea conținutului măsurării, fără ca cercetătorul să fie conştient de acest lucru.

\section{Erori de raportare sau de transcriere}

Aceste erori țin exclusiv de cercetător şi pot consta în: greşeli în codificarea datelor, erori de calcul, erori în citirea rezultatelor oferite de calculator, erori de transcriere etc.

\section{Erori datorate variabilelor străine}

Validitatea studiilor va fi diminuată sistematic de variabilele străine care au fost ignorate.

\section{Planificarea metaanalizei}

Dacă ar fi să apelăm la analogia făcută de Lipsey şi Wilson (2001) între metaanaliză şi un sondaj de opinie, am putea spune că etapele metaanalizei sunt foarte similare cu etapele unui sondaj de opinie.

În primul rând, atât în sondajele de opinie cât şi în metaanaliză trebuie delimitată şi formulată problema care se doreşte a fi investigată. Odată ce această etapă a fost depăşită, trebuie stabilită o strategie de eşantionare pentru identificarea subiecților (sau a rapoartele de cercetare) relevanți pentru studiu. $\mathrm{Cu}$ alte cuvinte, trebuie delimitată populația pe care vrem să o studiem.

Odată ce ştim cum ajungem la subiecți sau la rapoartele de cercetare, trebuie culese date relevante pentru problema la care încercăm să găsim un răspuns. Aşa cum cei care organizează şi derulează sondaje de opinie folosesc chestionare, cercetătorii care fac metaanalize vor utiliza foi de standardizare a rezultatelor. În strânsă relație cu acest moment, trebuie organizată o bază de date care să permită păstrarea, procesarea şi elaborarea de rapoarte.

Nu în ultimul rând, atât ancheta socială cât şi metaanaliza trebuie să se încheie cu un raport de cercetare.

\section{Formularea problemei de cercetare}

Ca orice demers ştiințific, metaanaliza porneşte de la formularea unor ipoteze de cercetare. Discutând problema ipotezelor în metaanaliză, Mullen (1989) susține că această etapă este crucială pentru buna desfăşurare a întregului demers, implicând decizii ale cercetătorilor în patru mari aspecte: (1)variabila dependentă, (2)variabila independentă, (3)eşantionare şi procedură şi (4)teste statistice utilizate.

În ceea ce priveşte variabila dependentă şi variabilele independente, două aspecte sunt importante: definirea conceptuală şi definirea operațională a acestora (Mullen, 1989). Definirea conceptuală se referă la suportul teoretic-conceptual al variabilelor şi reprezintă prima etapă a construirii unui test psihologic (Constantin, 2004, p. 74). Pornind de la această definire a variabilei ce urmează a fi măsurate, autorii testelor construiesc itemi care descriu (sau operaționalizează) comportamente concordante $\mathrm{cu}$ definiția conceptuală a constructului ce se doreşte a fi măsurat. În urma analizelor de itemi şi a analizelor factoriale utilizate în construcția testelor se ajunge la un set de itemi (comportamente) care reprezintă definiția operațională a respectivului construct.

În selectarea studiilor pentru metaanaliză, cercetătorul trebuie să țină cont de faptul că definițiile operaționale pot varia de la un instrument la altul, chiar dacă în construcție au pornit de la definiții conceptuale similare sau chiar identice. Diferența la nivelul definițiilor operaționale poate face ca legătura dintre constructul respectiv şi un alt construct să fie mai intensă sau mai puțin intensă. Mai mult, variante diferite ale aceloraşi instrumente duc la apariția diferențelor la nivelul definițiilor operaționale. $\mathrm{Cu}$ alte cuvinte, includerea în aceeaşi metaanaliză a studiilor care măsoară acelaşi construct cu instrumente diferite poate duce la rezultate eronate şi din acest motiv cercetătorul trebuie să țină cont de instrumentul folosit de autorii articolului pentru măsurarea variabilelor de interes.

Variația definiției operaționale poate duce la obținerea unor rezultate eterogene (care variază mai mult decât ne-am aştepta), dar acest lucru nu este obligatoriu. Recomandarea noastră pentru cei ce-şi propun să realizeze metaanalize este să includă studii care au utilizat instrumente diferite, dar să țină o evidență strictă a metodelor de culegere a datelor folosite de autorii respectivelor studii. În situația în care 
rezultatele raportate de studii nu sunt omogene, autorii metaanalizei au mai multe opțiuni care vor fi menționate ulterior în acest material.

\section{Identificarea studiilor relevante}

Identificarea studiilor relevante se face pe baza elementelor discutate anterior în secțiunea despre ipotezele metaanalizei. Căutarea articolelor se poate face utilizând baze de date online.

Pentru localizarea studiilor relevante, Mullen (1989) propune apelul la două strategii de căutare:

- $\quad$ strategia surselor (ancestry strategy) presupune căutarea noilor articole pornind de la bibliografia celor pe care le deținem deja. Rezultatul căutării va fi un set de articole mai vechi decât cele pe care le deținem deja, articole care la rândul lor pot sta la baza unei noi căutări pentru a identifica articole şi mai vechi;

- $\quad$ strategia descendenței (descendancy approach) - cercetătorul poate porni de la un articol sau o referința bibliografică foarte des citată, focalizându-şi căutarea pe noi manuscrise care au în bibliografie respectiva referință. $\bigcirc$ astfel de strategie este foarte eficientă atunci când se porneşte de la referințe în care sunt prezentate pentru prima oară probe psihologice consacrate deoarece asigură atât o stabilitate a instrumentelor de evaluare cât şi posibilitatea identificării unor articole care nu au ca principal obiectiv studiul variabilelor care ne interesează pentru metaanaliză. De exemplu, dacă efectuăm o căutare după articolul în care Bennet şi Robinson (2000) descriu chestionarul de evaluare a comportamentelor contraproductive, vom obține numai acele articole care au utilizat acest chestionar şi nu articole care au apelat la probe paralele (Spector, Fox, Penney, Bruusema, Goh \& Kessler, 2006, de exemplu). O astfel de abordare poate duce la creşterea rigurozității metaanalizei prin faptul că menține constantă definiția operațională a variabilei dependente.

În urma unei analize comparative a eficienței acestor strategii, Durlak (2005) afirmă că ele pot ajuta cercetătorul să identifice până la $80 \%$ din sursele care vor fi folosite în metaanaliză.

\section{Identificarea informațiilor relevante în cadrul studiilor}

Culegerea informațiilor relevante pentru metaanaliză se face în funcție de obiectivele cercetării şi în funcție de design-ul experimental al studiilor care sunt analizate (studii corelaționale, studii experimentale etc.). În această etapă este important ca problema ce se doreşte a fi studiată să fie cât mai bine delimitată din cele patru puncte de vedere discutate anterior.

Fiecare studiu conține mai multe tipuri de informații, fiecare cu utilitatea ei în demersul metaanalitic:

- $\quad$ informații de identificare a studiului;

- informații privind potențiale variabile moderatoare ale mărimii efectului.;

- informații pentru calcularea mărimii efectului.

Datele prezentate în tabelul 1 nu se doresc a fi exhaustive sau obligatorii. În funcție de specificul temei de cercetare lista de mai sus poate fi completată.

În acelaşi timp, culegerea tuturor acestor date nu garantează că toate vor fi utile cercetătorului deoarece este posibil ca relația studiată să fie una omogenă, ceea ce exclude analiza variabilelor moderatoare. Chiar şi în situații de eterogenitate a rezultatelor, este puțin probabil ca toate aceste date să fie utile în explicarea ei. Totuşi, omiterea unei informații în momentul culegerii datelor poate obliga cercetătorul să reia toate articolele pentru a introduce respectiva informatie.

\section{Derularea metaanalizei. Metaanaliza corelațiilor}

Materialul de față îşi propune prezentarea principalelor principii de analiză a omogenității studiilor care raportează coeficienți de corelație. În cazul studiilor care apelează la analize statistice ce implică comparații, principiile sunt relativ aceleaşi dar formulele de calcul sunt uşor diferite.

În cadrul acestui articol vom folosi ca exemplu un set de date reale culese din 31 de articole de specialitate, care raportează 42 de coeficienți de corelatie obținuti în urma testării unor eşantioane independente. Obiectivul metaanalizei exemplificate este de a clarifica relația dintre scalele Extraversiune şi Neuroticism din modelul Big Five. 
Tabelul 1. Tipuri de informații relevante şi utilitatea lor

\begin{tabular}{|c|c|c|}
\hline Tip informație & Date necesare & Utilitate \\
\hline $\begin{array}{l}\text { Date de } \\
\text { identificare a } \\
\text { studiului }\end{array}$ & $\begin{array}{l}\text {-autor(i); } \\
\text {-titlu; } \\
\text {-jurnal; } \\
\text {-număr; } \\
\text {-pagina. }\end{array}$ & $\begin{array}{l}\text { Aceste date sunt utile în păstrarea unei evidențe a studiilor introduse în } \\
\text { metaanaliză. Ele sunt utile în verificarea datelor culese, scrierea } \\
\text { bibliografiei şi în situația în care obiectivele şi ipotezele metaanalizei sunt } \\
\text { completate sau modificate. }\end{array}$ \\
\hline \multirow{6}{*}{$\begin{array}{l}\text { Caracteristici ale } \\
\text { eşantionului }\end{array}$} & $\begin{array}{l}\text {-volumul eşantionului } \\
\text { (N) }\end{array}$ & $\begin{array}{l}\mathrm{N} \text { este o informație centrală în calcularea indicatorilor de mărimea efectului } \\
\text { şi în calcularea rezultatelor metaanalizei. În absența acestei informații, } \\
\text { rezultatele studiului nu pot fi utilizate. }\end{array}$ \\
\hline & -distribuția de gen & $\begin{array}{l}\text { Cum o teorie nu poate fi valabilă doar pentru bărbați sau doar pentru femei, } \\
\text { este important ca pentru fiecare rezultat inclus în metaanaliză să ştim } \\
\text { distribuția de gen a eşantionului deoarece aceasta ar putea fi o importantă } \\
\text { variabilă moderatoare. }\end{array}$ \\
\hline & $\begin{array}{l}\text {-media de vârstă a } \\
\text { subiecților; } \\
\text {-abaterea standard a } \\
\text { mediei de vârstă; }\end{array}$ & $\begin{array}{l}\text { Media şi abaterea standard a vârstei subiecților sunt două variabile } \\
\text { importante deoarece ne permite identificarea şi izolarea studiilor care au } \\
\text { utilizat eşantioane omogene sau eterogene din punctul de vedere al vârstei }\end{array}$ \\
\hline & $\begin{array}{l}\text {-naționalitatea } \\
\text { subiecților }\end{array}$ & $\begin{array}{l}\text { Apelul la rezultatele cercetărilor derulate în țări diferite poate duce la } \\
\text { formularea unor concluzii cu un grad ridicat de generalitate. De Leeuw şi } \\
\text { Hox (2003) consideră chiar că luarea în considerare a acestor aspecte } \\
\text { poate clarifica o serie de variații interculturale ale efectului studiat. }\end{array}$ \\
\hline & $\begin{array}{l}\text {-distribuția etnică a } \\
\text { subiecților }\end{array}$ & $\begin{array}{l}\text { Foarte multe dintre studii (în special cele realizate în Statele Unite) au } \\
\text { eşantioane multi-etnice. Acest lucru poate influența variabile sensibile la } \\
\text { statutul de majoritate sau minoritate etnică şi cercetătorul trebuie să țină } \\
\text { cont de acest aspect. }\end{array}$ \\
\hline & $\begin{array}{l}\text {-date specifice } \\
\text { domeniului de } \\
\text { cercetare }\end{array}$ & $\begin{array}{l}\text { Pentru domeniul organizațional, potențiale variabile moderatoare sunt: } \\
\text { vechimea în muncă, tipul de angajați (full-time sau part-time), specificul } \\
\text { activității organizației (producție, servicii etc.); }\end{array}$ \\
\hline \multirow{3}{*}{$\begin{array}{l}\text { Caracteristici ale } \\
\text { variabilelor de } \\
\text { interes } \\
\text { (VI şi VD) }\end{array}$} & $\begin{array}{l}\text { - probe utilizate } \\
\text { (autori, variantă) }\end{array}$ & $\begin{array}{l}\text { Înregistrarea acestor informații dă posibilitatea cercetătorului să mențină } \\
\text { constantă variația definițiilor operaționale a constructelor analizate, variație } \\
\text { indusă de utilizarea unor probe diferite. }\end{array}$ \\
\hline & $\begin{array}{l}\text {-indicatori descriptivi } \\
\text { (medie, abatere } \\
\text { standard, valoare } \\
\text { minimă, valoare } \\
\text { maximă) }\end{array}$ & Aceşti indicatori vor fi folosiți în metaanaliza artefactelor. \\
\hline & -consistența internă & Aceşti indicatori vor fi folosiți în metaanaliza artefactelor. \\
\hline \multirow{5}{*}{$\begin{array}{l}\text { Caracteristici ale } \\
\text { design-ului } \\
\text { experimental }\end{array}$} & $\begin{array}{l}\text {-numărul de condiții } \\
\text { experimentale }\end{array}$ & \\
\hline & $\begin{array}{l}\text {-modul de formare a } \\
\text { condițiilor } \\
\text { experimentale }\end{array}$ & $\begin{array}{l}\text { Variabilă discretă/dihotomizare } \\
\text { Aleatoare/non-aleatoare } \\
\text { Test/retest }\end{array}$ \\
\hline & $\begin{array}{l}\text {-numărul de subiecți } \\
\text { din fiecare grupă } \\
\text { experimentală }\end{array}$ & \\
\hline & $\begin{array}{l}\text {-procedura } \\
\text { experimentală }\end{array}$ & \\
\hline & -alte caracteristici & $\begin{array}{l}\text { Ex.: materiale folosite (texte, desene, grafice etc.), sarcini date subiecților } \\
\text { (calcul numeric, completare formulare etc.). }\end{array}$ \\
\hline Rezultate obținute & $\begin{array}{l}\text {-indicatori ai mărimii } \\
\text { efectului; } \\
\text { sau } \\
\text {-valoarea şi gradele } \\
\text { de libertate ale } \\
\text { testelor statistice } \\
\text { folosite }\end{array}$ & $\begin{array}{l}\text { Datele necesare pentru calcularea mărimii efectului variază în funcție de } \\
\text { indicatorul calculat şi în funcție de design-ul experimental. }\end{array}$ \\
\hline
\end{tabular}


Datele culese sunt prezentate în Tabelul 2. După cum se poate observa, au fost înregistrate informații privind numărul de subiecți, procentul de subiecți de gen feminin, media de vârstă a subiecților, abaterea standard a mediei de vârstă, naționalitatea subiecților, proba utilizată pentru măsurarea variabilelor din modelul Big Five, valoarea coeficientului de corelatie.

Tabelul 2. Baza de date utilizată

\begin{tabular}{|c|c|c|c|c|c|c|c|c|}
\hline STUDIU & $\mathrm{N}$ & $\% \mathrm{~F}$ & $\begin{array}{l}\text { medie } \\
\text { vârsta }\end{array}$ & $\begin{array}{c}\text { AS } \\
\text { vârsta }\end{array}$ & $\begin{array}{c}\text { Tip } \\
\text { subiecți }\end{array}$ & Naționalitate & $\begin{array}{c}\text { Proba } \\
\text { Big Five }\end{array}$ & $r$ \\
\hline Antonioni (1998) & 120 & 45.00 & & & manageri & SUA & Costa \& McCrae 1985 & -.45 \\
\hline Antonioni (1998) & 351 & 58.00 & & & studenți & SUA & Costa \& McRae 1985 & -.30 \\
\hline Avery (2003) & 96 & 67.00 & & & studenți & SUA & Goldberg 1992 & .02 \\
\hline Aziz \& Jackson (2001) & 160 & 32.50 & 23.09 & 1.93 & studenți & Pakistan & John et el 1991 & -.27 \\
\hline Bartone \& Snook (2002) & 855 & 12.00 & 18.61 & .88 & studenți & SUA & Costa \& McCrae 1985 & -.37 \\
\hline Becker (1999) & 113 & 72.00 & 24.20 & 6.60 & studenți & Germania & Andersen 1995 & -.30 \\
\hline Becker (1999) & 113 & 72.00 & 24.20 & 6.60 & studenți & Germania & Costa \& McCrae 1985 & .17 \\
\hline Becker (1999) & 113 & 72.00 & 24.20 & 6.60 & studenți & Germania & Ostendorf 1990 & -.42 \\
\hline Bernard et al (2002) & 111 & 100.00 & 19.70 & 3.40 & studenți & SUA & Costa \& McCrae 1992 & -.32 \\
\hline Bernard et al (2002) & 79 & 0 & 19.70 & 3.40 & studenți & SUA & Costa \& McCrae 1992 & -.39 \\
\hline Chapman, Hayslip (2005) & 292 & 74.30 & 19.68 & 2.77 & studenți & SUA & Costa \& McCrae 1992 & -.39 \\
\hline Conte si Jacobs (2003) & 181 & 14.00 & 42.60 & 7.67 & studenți & SUA & Hogan 1990 & .28 \\
\hline De Young et al (2002) & 222 & 64.00 & 24.50 & 7.00 & & Canada & Goldberg 1992 & -.07 \\
\hline De Young et al (2002) & 245 & 69.00 & 21.00 & 3.10 & studenți & Canada & Costa \& McCrae 1992 & -.37 \\
\hline De Young et al (2002) & 245 & 69.00 & 21.00 & 3.10 & studenți & Canada & Goldberg 1992 & -.27 \\
\hline Dwight et al (1998) & 437 & 67.00 & 21.37 & 4.49 & studenți & SUA & Goldberg 1992 & -.35 \\
\hline Ebert et al (2002) & 202 & 70.00 & 20.70 & 4.60 & studenți & SUA & Costa \& McCrae 1985 & -.33 \\
\hline Gelade (2002) & 82 & 35.00 & 33.70 & 9.50 & angajați & UK & Costa \& McCrae 1992 & -.13 \\
\hline Graziano Tobin (2002) & 316 & 40.00 & & & studenți & SUA & Goldberg 1992 & -.30 \\
\hline Kelly \& Pulver (2003) & 566 & 51.00 & & & studenți & SUA & Costa \& McCrae 1992 & -.33 \\
\hline Kwapil (2002) & 858 & 73.00 & & & studenți & SUA & Costa \& McCrae 1992 & -.28 \\
\hline Lievent \& Fruit (2001) & 403 & 46.00 & 33.00 & 7.25 & & Belgia & Hofstee et al 1992 & .02 \\
\hline Lounsbury et al (2003) & 646 & 53.00 & & & liceu & SUA & Lounsbury et al & -.14 \\
\hline Lounsbury et al (2003) & 355 & 49.00 & & & studenți & SUA & Costa \& McCrae 1992 & -.38 \\
\hline Mak \& Tran (2001) & 124 & 37.00 & 22.70 & 4.74 & studenți & Vietnam & Costa \& McCrae 1992 & -.11 \\
\hline Meyer (2002) & 212 & 43.00 & 24.75 & 3.26 & studenți & Germania & Costa \& McCrae 1989 & -.39 \\
\hline OBrien (1996) & 270 & 63.00 & 21.00 & & studenți & UK & Costa \& McCrae 1989 & -.34 \\
\hline Penley \& Tomaka (2002) & 97 & 34.00 & 21.02 & 4.79 & studenți & SUA & Costa \& McCrae 1985 & -.25 \\
\hline Robins (2001) & 270 & 59.00 & 18.00 & & studenți & SUA & Costa \& McCrae 1992 & -.37 \\
\hline Robins (2001) & 270 & 59.00 & 22.00 & & studenți & SUA & Costa \& McCrae 1992 & -.37 \\
\hline Rose et al (2002) & 96 & 50.00 & 19.30 & & studenți & SUA & Costa \& McCrae 1992 & -.11 \\
\hline Sadowsky et al (1997) & 85 & 60.00 & 19.72 & 1.31 & studenți & SUA & Costa \& McCrae 1992 & -.45 \\
\hline Shafer (2001) & 374 & 63.00 & 20.00 & 2.70 & studenți & SUA & Shafer 1999 & -.30 \\
\hline Thompson et al. (2002) & 106 & 86.00 & 34.70 & & studenți & SUA & Costa \& McCrae 1992 & -.22 \\
\hline Thoms \& Moore (1996) & 126 & 9.00 & 42.00 & & angajați & SUA & Costa \& McCrae 1992 & -.40 \\
\hline Trull \& Geary (1997) & 198 & 52.00 & 20.00 & 1.30 & studenți & China & Goldberg 1992 & -.52 \\
\hline Trull \& Geary (1997) & 303 & 66.00 & 20.00 & 3.10 & studenți & SUA & Goldberg 1992 & -.63 \\
\hline Tsaousis (2001) & 225 & 57.00 & & & angajați & Grecia & Tsaousis 1998 & -.33 \\
\hline Tsaousis (2001) & 561 & 64.90 & 26.80 & 4.35 & şomeri & Grecia & Tsaousis 1998 & -.33 \\
\hline Tsaousis (2001) & 1054 & 61.00 & 19.90 & 4.32 & studenți & Grecia & Tsaousis 1998 & -.35 \\
\hline Tuten \& Bosnjak (2001) & 400 & 51.00 & & & studenți & SUA & Goldberg 1992 & -.31 \\
\hline Wilsonsi colab (2004) & 883 & 69.10 & 75.10 & 7.10 & bătrâni & SUA & Costa \& McCrae 1992 & -.39 \\
\hline
\end{tabular}


Pe baza unei simple inspecție vizuale a acestei baze de date putem face mai multe observații, după cum urmează:

- numărul subiecților din fiecare studiu variază foarte mult (între $\mathrm{N}=79$ şi $\mathrm{N}=1054$ );

- distribuția de gen în cadrul eşantioanelor analizate variază între 0 şi 100\% subiecți de gen feminin;

- vârsta medie a subiecților variază între 18 şi 75 de ani;

- 34 dintre cele 42 de eşantioane au fost de studenți;

- aproximativ jumătate dintre studii sunt derulate pe eşantioane din Statele Unite;

- $\quad$ au fost folosite instrumente diferite pentru măsurarea factorilor modelului Big Five;

- există studii care raportează rezultate obtinute utilizând aceeaşi probă pe eşantioane diferite (de exemplu Antonioni, 1998) şi studii care au aplicat mai multe probe paralele la acelaşi eşantion, oferind mai multe rezultate ale aceluiaşi eşantion (de exemplu Becker, 1999).

\section{Principii de calcul în metaanaliză}

După cum am afirmat anterior, metaanaliza îşi propune identificarea unui efect mediu şi stabilirea unui interval de încredere al acestui efect. Principala diferență dintre calculele statistice $\mathrm{cu}$ care suntem obişnuiți şi calculele necesare pentru derularea unei metaanalize constă în faptul că acestea din urmă sunt statistici ponderate.

În mod normal, calculul mediei unui şir de numere este relativ simplu: media este suma acestora împărțită la numărul de elemente care compun suma (N). În această situație, ponderile elementelor sunt egale (fiecare element are ponderea 1). Un exemplu de medie neponderată este media anilor de liceu, în care nota la purtare este egală ca pondere cu nota la engleză, matematică, română etc.

Calculul mediei ponderate se face prin modificarea importanței fiecărui element în calcularea acestui indicator. Dacă în exemplul anterior ponderea fiecărui element care intră în calcul este 1, în cazul mediei ponderate fiecare element are o importanță diferită. Un exemplu în acest sens este media anuală a unui student, care se calculează ținând cont de numărul de credite al fiecărei discipline. Media anuală ponderată se va calcula după formula:

$$
m=\frac{\sum \text { nota } \times \text { nr.credite }}{\sum n \text {.credite }}
$$

Astfel, notele obținute la discipline cu un număr mai mare de credite vor "atârna mai greu" în cazul mediei generale a studentului respectiv.

În mod similar, în derularea metaanalizei vom identifica studii care sunt mai importante şi studii care sunt mai puțin importante. Autori clasici în domeniul metaanalizei (Hedges, Rosenthal, Hunter şi Schmidt) recomandă ca gradul de importanță a studiilor în calcularea mediei ponderate să fie dat de inversul varianței mărimii efectului raportate de studiu (1/ $\left.\operatorname{var}_{\text {studiu }}\right)$. Argumentul acestui criteriu de ponderare este relativ simplu: sunt mai importante acele studii care raportează efecte al căror interval de încredere este mai scăzut (au o varianță mai mică), comparativ cu studiile care raportează efecte cu interval de încredere mare.

În funcție de mărimea efectului luată în considerare în metaanaliză, această varianță se calculează diferit (pentru mai multe detalii, vezi Durlak, 2005; Kirk, 2005). În cazul coeficientului de corelație $r$ (Pearson) varianța mărimii efectului este $1 /(\mathrm{N}-3)$, unde $\mathrm{N}$ este numărul de subiecți testați.

\section{Testarea heterogenității studiilor}

Testarea heterogenității studiilor reprezintă, alături de metaanaliza "oaselor goale", o formă de metaanaliză care are ca obiectiv identificarea impactului erorii de eşantionare asupra efectelor obținute de studii diferite. Metodologia testării heterogenității studiilor este prezentată pe larg în Miclea (1994) şi Hohn şi colab. (1999).

Testarea heterogenității studiilor are la bază testul $X^{2}$, care testează existența diferențelor dintre valorile observate şi valorile aşteptate (Sava, 2004). Într-un studiu metaanalitic, se utilizează $X^{2}$ pentru a testa diferențele dintre valorile obținute de studii diferite şi valoarea mediei ponderate a acestor studii.

Calcularea mediei mărimii efectului reprezintă primul pas al oricărei metaanalize. Această medie este denumită „medie observată" şi se obține ținându-se cont de numărul de subiecți ai fiecărui studiu, astfel încât studiile cu un număr mare de subiecți (deci cu o eroare de eşantionare mai mică) să aibă o pondere mai mare în această medie 
(Formula 2). De asemenea, este important de menționat faptul că, pentru calcularea mediei mărimii efectului, $s-a$ folosit transformata $z$ (Fisher) a coeficienților de corelație.

$$
z_{\text {mediu.observat }}=\frac{\sum\left[z_{\text {studiu }} \times\left(N_{\text {studiu }}-3\right)\right]}{\sum_{\text {(Formula 2 })}\left(N_{\text {studiu }}-3\right)}=-0,3192
$$

Odată calculată media ponderată a mărimii efectului, se poate calcula valoarea testului $X^{2}$ pentru a vedea dacă diferențele existente între mărimile efectului raportate de studii (valori observate) şi media calculată (valoarea aşteptată) sunt semnificative. În literatura de specialitate, testul folosit pentru evaluarea eterogenității este notat $\mathrm{cu} Q$ (Rosenthal şi colab. 2006). Formula de calcul este următoarea:

$$
Q=\sum\left[\left(N_{\text {studiu }}-3\right) \times\left(z_{\text {studiu }}-z_{\text {mediu.observat }}\right)^{2}\right]=299,87
$$

(Formula 3)

Aflarea pragului de semnificație a testului de omogenitate se face cu ajutorul tabelelor lui $X^{2}$, la un grad de libertate egal cu numărul de eşantioane (notat în mod uzual cu litera $k$ ) minus 1 . În situația noastră $\mathrm{Q}(41)=299,87$ are un prag de semnificație mai mic de .0001, ceea ce indică faptul că diferentele dintre studiile incluse în metaanaliză se datorează şi altor factori în afara erorii de eşantionare.

Principala problemă a acestui rezultat este eterogenitatea mare a studiilor incluse în metaanaliză, deoarece calcularea unui interval de încredere a mediei observate a efectelor raportate este condiționată de omogenitatea acestora.

Un astfel de rezultat impune identificarea variabilelor moderatoare (artefacte de cercetare) care duc la apariția sistematică a unor rezultate diferite. Principalele modalități de identificare a acestor artefacte şi de evidențiere a efectelor lor vor $\mathrm{fi}$ însă obiectul unui articol viitor.

\section{Metaanaliza „oaselor goale”*}

Denumirea de metaanaliza a "oaselor goale" (bare-bones meta-analysis - Hunter \& Schmidt, 2004) provine de la încercarea acestui demers de a cuantifica şi de a evalua

această prezentare este un rezumat al metodologiei descrisă de Hunter şi Schmidt (2004, p.81-88) influența erorii de eşantionare. Rezultatul unei astfel de analize este o estimare a variației mărimii efectului de la un studiu la altul, în absența oricărei influențe din partea erorii de eşantionare.

Teoria ce stă în spatele acestui tip de metaanaliză este relativ simplă: dispersia rezultatelor raportate de studii $\left(S_{\text {total }}^{2}\right)$ este suma influentei artefactelor de cercetare descrise anterior. Diferențele datorate erorii de eşantionare $\left(S_{1}^{2}\right)$, diferențele datorate variațiilor de consistență internă $\left(S_{2}^{2}\right)$ şi diferențele datorate restricțiilor de amplitudine $\left(S_{3}^{2}\right)$ contribuie în mod cumulativ la diferențele pe care ajungem să le observăm atunci când dorim să derulăm o metaanaliză (vezi Formula 4).

$$
S_{\text {total }}^{2}=S_{1}^{2}+S_{2}^{2}+S_{3}^{2}+S_{\text {necunoscut }}^{2}
$$

(Formula 4)

Abordarea propusă de Hunter şi Schmidt (2004) constă în calcularea puterii explicative a fiecărui artefact. De exemplu, dacă ajungem să cunoaştem $S_{\text {total }}^{2}$ şi $S_{1}^{2}$ (dispersia datorată erorii de eşantionare), putem calcula în ce măsură eroarea de eşantionare joacă un rol mai mult sau mai puțin important în explicarea diferențelor observate între studii ( $S_{1}^{2} / S_{\text {total }}^{2}$ ).

Prima etapă a oricărui demers metaanalitic constă în calcularea indicatorului de mărimea efectului pentru coeficienții de corelație. Deşi inițial pentru metaanalizele corelațiilor indicatorul de mărimea efectului general acceptat a fost coeficientul z(Fisher), ulterior Hunter şi Schmidt (2004) au constatat că această transformare nu este decât în mică măsură eficientă, în sensul că nu corectează suficient de mult distributia de frecvență a coeficienților de corelație. Deci în cazul nostru nu vom efectua nicio transformare a coeficienților de corelație. În cazul de față, în urma aplicării Formulei 2, obținem un coeficient de corelație mediu egal cu -.3036.

Odată calculată valoarea medie observată a mărimii efectului, se poate calcula varianța acesteia în eşantionul de studii $\left(S_{\text {total }}^{2}\right)$. Acest indicator ne indică gradul în care rezultatele diferitelor studii sunt asemănătoare sau diferite de media calculată prin Formula 2. 


$$
S_{\text {total }}^{2}=\frac{\sum\left[\left(r_{\text {studiu }}-r_{\text {mediu.observat }}\right)^{2} \times\left(N_{\text {studiu }}-3\right)\right]}{\sum\left(N_{\text {studiu }}-3\right)}=0,0197
$$

(Formula 5)

O valoare crescută a $S_{\text {total }}^{2}$ indicator nu ne spune nimic despre omogenitatea mărimii efectului deoarece dispersia datorată erorii de eşantionare $\left(S_{1}^{2}\right)$ nu a fost calculată încă. Formula de calcul a lui $S_{1}^{2}$ este prezentată mai jos (Formula 6).

$$
S_{1}^{2}=\frac{\left(1-r_{\text {mediu.observat }}\right)^{2}}{N_{\text {mediu }}-1}=0,0055
$$

(Formula 6)

După cum se poate observa, în această formulă se utilizează $N_{\text {mediu, }}$ care reprezintă media numărului de subiecți din studiile incluse în metaanaliză.

Diferența dintre varianța observată $\left(S_{\text {total }}^{2}\right)$ şi varianța datorată erorii de eşantionare $\left(S_{1}^{2}\right)$ reflectă „varianța reală” a mărimii efectului la nivelul populației (Hunter \& Schmidt, 2004; Huffcutt, 2007). Dacă varianța reală a mărimii efectului este mare, putem vorbi de 0 situație de eterogenitate a rezultatelor diferitelor studii şi ar trebui să încercăm să explicăm această variabilitate pe baza caracteristicilor studiilor. Pentru identificarea situației de eterogenitate a rezultatelor studiilor incluse în metaanaliză, Hunter şi Schmidt (2004) recomandă raportarea varianței de eşantionare la varianța observată a mărimii efectului.

$$
\frac{S_{1}^{2}}{S_{\text {total }}^{2}}=\frac{0,0055}{0,0197}=0,2836 \quad \text { (Formula 7) }
$$

În situația în care raportul de mai sus este mai mic de .75 putem vorbi de rezultate eterogene deoarece un astfel de rezultat ne indică faptul că peste $25 \%$ din varianța rezultatelor studiilor se datorează unor variabile care nu au fost luate în calcul. În cazul datelor noastre, se poate observa faptul că erorile de eşantionare joacă un rol foarte mic în explicarea diferențelor dintre studii. Din varianța totală de 0,0197 , doar o mică parte poate fi atribuită erorilor de eşantionare $(0,0055)$, adică aproximativ $28 \%$. Restul de până la $100 \%$ poate fi atribuit unor diferențe între studiile incluse în metaanaliză, diferențe despre care nu ştim nimic.
În fața unui astfel de rezultat, cercetătorul trebuie să încerce să reducă proporția varianței neexplicate, ceea ce presupune reducerea influenței artefactelor prezentate anterior astfel încât se se ajungă la un procent cât mai mic de varianță neexplicată. Dacă cercetătorul nu are suficiente informații pentru a detecta influența variabilelor moderatoare sau a artefactelor de cercetare, el va calcula intervalul de încredere

al lui $r_{\text {mediu.observat }}$.

$$
\begin{aligned}
& r_{\min }=r_{\text {mediu.observat }}-1,96 \times \sqrt{S_{\text {total }}^{2}-S_{1}^{2}}=-0.536 \\
& r_{\text {min }}=r_{\text {mediu.observat }}+1,96 \times \sqrt{S_{\text {total }}^{2}-S_{1}^{2}}=-0.070
\end{aligned}
$$

Analiza prezentată până în acest moment a identificat 0 corelație negativă medie între Extraversiune şi Neuroticism, corelație care poate varia între $r=-.070$ şi $r=-$ .536. Acest rezultat este unul relevant (deoarece intervalul de încredere nu include valoarea "0"), dar în acelaşi timp nu este un rezultat foarte bun deoarece ponderea varianței neexplicate din varianța totală este încă foarte mare.

Chiar dacă metoda propusă de Hunter şi Schmidt (2004) permite calcularea intervalului de încredere în situații de eterogenitate prin eliminarea dispersiei generată de eroarea de eşantionare, rezultatul în sine nu este unul valoros pentru cercetările viitoare deoarece intervalul de încredere al mediei efectului studiilor incluse în analiză este totuşi unul foarte mare.

Eterogenitatea rezultatelor studiilor introduse în metaanaliză obligă cercetătorul să încerce să explice acest rezultat. Rezultatele obținute în exemplul prezentat în acest material sunt eterogene atât din punctul de vedere al testului de eterogenitate $(Q(41)=299,87, p<.0001)$, cât şi din punctul de vedere al metaanalizei "oaselor goale" (varianța neexplicată este de aproximativ $70 \%)$.

Huffcut (2007) descrie mai multe modalități de reducere a varianței neexplicate, după cum urmează:

- izolarea studiilor pe baza unui criteriu stabilit de cercetător sau prin analiză de cluster;

- eliminarea influențelor artefactelor de cercetare;

- introducerea rezultatelor într-o analiză statistică (analiză de regresie sau analiză de varianță), în încercarea de 
a explica variațiile acestora pe baza caracteristicilor studiilor.

Din considerente legate de spațiul avut la dispoziție, fiecare dintre aceste metode vor $\mathrm{fi}$ analizate într-un material viitor.

\section{Raportarea rezultatelor obținute}

Ca orice demers ştiințific, rezultatele obținute în urma derulării unei metaanalize trebuie raportate într-o formă standardizată care să cuprindă (Huffcut, 2007; Durlak, 2005):

- modalitatea de căutare a studiilor incluse în metaanaliză;

- $\quad$ principalele decizii luate pe parcursul selecției studiilor;

- $\quad$ principalele rezultate obținute.

În ceea ce priveşte modalitatea de căutare a studiilor incluse în metaanaliză, de obicei se raportează bazele de date internaționale în care s-a realizat căutarea şi cuvintele cheie utilizate în această căutare. În situația în care s-au utilizat şi alte strategii, acestea trebuiesc raportate (vezi Caseta 1).

Deciziile luate pe parcursul selecției studiilor se referă la includerea unor criterii în selecție, criterii care se pot referi la:
- $\quad$ selectarea studiilor care au folosit doar un anumit instrument - în cazul nostru, am fi putut include în metaanaliză doar studii care au utilizat un anumit chestionar de măsurare a dimensiunilor modelului Big Five. $\mathrm{O}$ astfel de decizie poate fi justificată de încercarea de a menține constantă definiția operațională a unei variabile relevante;

- selectarea studiilor care au apelat doar la o anumită teorie - în cazul nostru, în studierea relației ExtraversiuneNeuroticism am fi putut include şi studii care au utilizat teoria lui Eysenck asupra personalității. Decizia de a nu include astfel de studi poate fi justificată de încercarea de a menține constantă definiția conceptuală a variabilelor relevante;

- selectarea studiilor care au apelat doar la un anumit tip de subiecți - în cazul nostru, am fi putut include în metaanaliză doar acele studii care au apelat la subiecți studenți.

Caseta 1. Exemplu de raportare a selecției studiilor şi a deciziilor luate în această etapă

Căutarea articolelor s-a realizat prin folosirea unor cuvinte cheie în baza de date PsychInfo, ProQuest, Ebsco, Science Direct, PsychArticles, JSTOR, ScienceDirect (folosind cuvinte cheie: workplace deviance, counterproductive work behavior, organizational misbehavior, interpersonal workplace deviance, organizational workplace deviance, antisocial behavior at work, employee deviance). Au fost căutate în special articolele care au folosit scala lui Bennett şi Robinson (2000) satt Robinson şi Bennett (1995) şi au fost luate în considerare doar articolele care au folosit aceste scale sau scale care au la bază acest model bidimensional - al devianței organizaţionale şi interpersonale. De asemenea, au fost identificate şi lucrările prezentate la diferite conferințe în domeniul psihologiei organizaționale. $\mathrm{O}$ altă modalitate de căutare a articolelor a fost reprezentată de analiza bibliografiei metaanatizelor anterioare.
Baze de date internaționale şi cuvinte cheie folosite.

Decizii luate în căutarea articolelor

Alte metode de identificare a cercetărilor relevante.

Exemplu preluat din Pitariu, Sulea, Zaborilă şi Maricuțoiu (2008).

În raportarea rezultatelor obținute, trebuie incluse informații precum: numărul de eşantioane analizate $(k)$, numărul total al subiecților testați în aceste eşantioane $(N)$, valoarea medie observată a mărimii efectului, abaterea standard a mediei mărimii efectului, intervalul de încredere al acestei valori medii şi indici statistici privind omogenitatea rezultatelor raportate de studiile incluse în analiză ( $Q$ sau varianța explicată de eroarea de eşantionare, în funcție de metoda utilizată în metaanaliză). 
Tabelul 3. Exemplu de raportare a rezultatelor metaanalizei

\begin{tabular}{cccccccc} 
Relație & $\mathrm{N}$ & $\mathrm{k}$ & $\mathrm{r}(\mathrm{obs})$ & $\mathrm{SD}(\mathrm{r} . \mathrm{aj})$ & $\mathrm{r}(\min )$ & $\mathrm{r}(\max )$ & $\%$ er.esant. \\
\hline E-N & 12815 & 42 & $-0,3036$ & 0,140 & $-0,536$ & $-0,070$ & $28,36 \%$
\end{tabular}

Legendă: $N=$ numărul cumulat de subiecți din toate studiile luate în considerare; $k=$ numărul de studii luate în

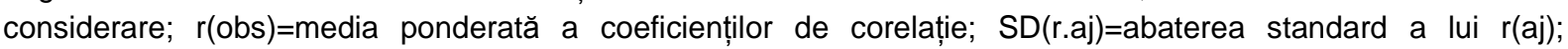
$r(\min )=$ limita inferioară a intervalului de încredere al coeficientului de corelație $(\alpha=.05) ; r(\max )=$ limita superioară a intervalului de încredere al coeficientului de corelație $(\alpha=.05)$; \%er.eşant.=procentul de varianță observată care poate fi atribuit erorilor de eşantionare.

Un tabel precum cel prezentat anterior permite raportarea într-o manieră sintetică a metaanalizei mai multor relații, prin introducerea unor rânduri suplimentare. Evident, pentru fiecare relație analizată, cercetătorul trebuie să parcurgă toate etapele de calcul descrise în acest articol, pentru a putea obține indicatorii necesari pentru formularea unei concluzii.

\section{Calitatea metaanalizei derulate}

O întrebare frecventă care apare în momentul în care ne propunem să începem o metaanaliză se referă la modalitatea de a realiza o metaanaliză de calitate asupra relației care ne interesează. Răspunsul la această întrebare depinde de mai mulți factori, după cum urmează: gradul de standardizare a metodologiei folosite în studiile care analizează relația pe care dorim să o investigăm, calitatea acestor studii şi numărul de studii disponibile $(k)$.

În primul rând, o trecere în revistă a metodologiei folosite în literatura de specialitate ar trebui să ofere răspunsul la întrebări de genul: care sunt metodele de culegere a datelor? sunt aceste metode echivalente astfel încât să poată fi combinate? Un grad înalt de standardizare a metodologiei folosite asigură replicabilitatea rezultatelor obținute, ceea ce constituie o premisă a demersului metaanalitic. Folosirea unor metode variate de culegere a datelor poate reprezenta un artefact care influențează eterogenitatea rezultatelor raportate de studii diferite, ducând astfel la un rezultat neconcludent (Hunter \& Schmidt, 2004).

Calitatea studiilor incluse în metaanaliză reprezintă încă un aspect dezbătut în literatura de specialitate deoarece nu există o definiție formală a acesteia (Greenland \& O'Rourke, 2001). Calitatea studiilor este legată în special de validitatea lor internă, de folosirea unor metode statistice adecvate design-ului experimental sau de nerespectarea condițiilor de utilizare a testelor psihologice. Aceste aspecte trebuie evaluate, iar pe baza acestei evaluări se ia decizia includerii studiului în metaanaliză. Unii autori (Hunter \& Schmidt, 2004; Lipsey \& Wilson, 2001) recomandă folosirea de experți care, în baza unei grile, să evalueze calitatea studiilor. Indicii de calitate astfel obținuți vor fi utilizați în ponderarea rezultatelor studiilor, rezultatul mediu obținut fiind astfel dublu ponderat: în baza varianței mărimii efectului şi în baza acestor indici de calitate.

Numărul articolelor necesare pentru a derula o metaanaliză de calitate este un aspect incert în literatura de specialitate. Pe de o parte, acesta ar trebui să fie cât mai mare pentru a asigura un nivel mai ridicat de generalizare a rezultatului. Pe de altă parte, metaanalizele publicate sunt derulate în frecvent pe un număr relativ redus de studii: de exemplu, Rosenthal şi DiMatteo (2001) prezintă un tabel sintetic cu studii care au apelat la metaanaliza prin testarea eterogenității, iar parametrul $k$ (numarul de eşantioane independente luate în considerare) variază 5 eşantioane şi 76 de eşantioane. În mod curent, revistele de specialitate publică metaanalize care raportează rezultate medii înregistrate prin cumularea a 4-7 studii.

La începuturile metodei, cercetătorii calculau un indicator al gradului de adecvare al numărului de studii: N-adițional (Miclea, 1994, p. 333). În momentul apariției acestui indicator, tehnicile metaanalitice porneau de la premiza că studiile reflectă variația unui efect fix, care nu variază (fixed effects meta-analysis Hunter \& Schmidt, 2000). Astăzi acest indicator nu este considerat relevant în toate situațiile deoarece marea majoritate a tehnicilor metaanalitice pornesc de la premiza că efectul mediu variază de la un studiu la altul (random effects meta-analysis- Hunter \& Schmidt, 2000). Cum în metaanaliza "oaselor goale" se calculează un indicator al dispersiei mărimii medii a efectului $\left(S_{1}^{2}\right)$ cercetătorul se aşteaptă ca acest efect să varieze de la un studiu la altul, ceea ce contrazice premizele de utilizare ale indicatorul $\mathrm{N}$-adițional ca reper 
pentru evaluarea gradului de adecvare a studiilor incluse în metaanaliză (Hunter \& Schmidt, 2004).

Relația dintre numărul de eşantioane incluse în metaanaliză $(k)$ şi calitatea acesteia depinde în primul rând de cei doi parametri discutați anterior: studiile trebuie să fie de calitate şi să aibă metodologii similare (de dorit ar fi ca metodele folosite să fie identice, dar acest lucru nu este întotdeauna posibil). În al doilea rând, rezultatul metaanalizei trebuie să fie unul omogen. În situația în care cercetătorul ajunge la un rezultat eterogen în baza unui număr relativ mic de studii (4-7 studii) el nu va mai avea posibilitatea de a studia sursa acestei eterogenități, ceea ce implică neatingerea unui obiectiv important al cercetării metaanalitice.

În concluzie, o metaanaliză de calitate este un demers care sintetizează cercetări de calitate (sintagma garbage in-garbage out este cât se poate de potrivită în acest context), cu metodologii similare sau identice şi ajunge la un rezultat omogen. După cum se poate observa, am exclus criteriul numărului de studii tocmai datorită faptului că între acesta şi omogenitatea rezultatului metaanalizei nu există o relație.

\section{Rezumat}

În articolul de față sunt discutate principiile fundamentale ale metaanalizei, ca tehnică statistică de sumarizare a rezultatelor obținute în studii corelaționale. Sunt abordate probleme fundamentale precum: finalitatea metaanalizei şi problematica artefactelor de cercetare. Articolul conține o serie de recomandări privind: selectarea studiilor pentru a fi incluse în metaanaliză, identificarea informațiilor relevante existente în aceste studii, calcularea efectului mediu al studiilor, al intervalului de încredere şi al indicilor de eterogenitate a rezultatului obținut. În final, sunt prezentate modalitățile de raportare a rezultatelor metaanalizei.

Cuvinte cheie: metaanaliză, corelații, metode statistice

\section{Bibliografie}

Albu, M. (1998). Construirea şi utilizarea testelor psihologice. Cluj Napoca: Clusium.

Antonioni, D. (1998). Relationship between the big five personality factors and conflict management styles. International Journal of Conflict Management, 9, 336-355.
Avery, D.R. (2003). Personality as a Predictor of the Value of Voice. The Journal of Psychology, 137, 435-446.

Aziz, S. \& Jackson, C.J. (2001). A comparison between three and five factor models of Pakistani personality data. Personality and Individual Differences, 31, 1311-1319.

Bartone, P.T., Snook, S.A. \& Tremble, T.R. (2002). Cognitive and Personality Predictors of Leader Performance in West Point Cadets. Military Psychology, 14, 321-338.

Becker, P. (1999). Beyond the Big Five. Personality and Individual Differences, 26, 511-530.

Bennett, R.J. \& Robinson, S.L. (2000). Development of a measure of workplace deviance. Journal of Applied Psychology, 85 (3), 349-360.

Bernard, N.S., Dollinger, S.J. \& Ramaniah, N.V. (2002). Applying the Big Five Personality Factors to the Impostor Phenomenon. Journal of Personality Assessment, 78, 321333.

Borenstein, M., Rothstein, H., \& Cohen, J. (2001) Power and Precision. Disponibil la: www.poweranalysis.com.

Chapman, B.P. \& Hayslip, B. (2005). Incremental Validy of a Measure of Emotional Intelligence. Journal of Personality Assessment, 85, 154-169.

Constantin, T. (2004). Evaluarea psihologică a personalului. Iaşi: Polirom.

Conte, J.M. \& Jacobs, R.R. (2003). Validity Evidence Linking Polychromicity and Big Five Personality Dimensions to Absence, Lateness, and Supervisory Performance Ratings. Human Performance, 16, 107-129.

Cronbach, L.J. \& Shavelson, R.J. (2004). My Current Thoughts on Coefficient Alpha and Successor Procedures. Educational and Psychological Measurement, 64, 391-418.

De Leeuw, E.D. \& Hox, J.J. (2003). The Use of Meta-Analysis In Cross-National Studies. în Harkness, J.A., van de Vijver, F.J.R. \& Mohler, P.Ph. (coord.) Cross-Cultural Survey Methods, New York: Wiley.

DeYoung, C.G., Peterson, J.B. \& Higgins, D.M. (2002). Higher-order factors of the Big Five predict conformity: Are there neuroses of health? Personality and Individual Differences, 33, 533-552.

Durlak, J.A. (2005). Basic Principles of Metaanalysis. în Roberts, M.C. \& Ilardi, S.S. (coord.): Handbook of research methods in Clinical Psychology, Blackwell Publishing House.

Dwight, S.A., Cummings, K.M. \& Glenar, J.L.(1998). Comparison of Criterion-Related Validity Coefficients for the Mini-Markers and Goldberg's Markers of the Big Five 
Personality Factors. Journal of Personality Assessment, 70, 541-550.

Ebert, S.A., Tucker, D.C. \& Roth, D.L. (2002). Psychological resistance factors as predictors of general health status and physical symptom reporting. Pychology, Health and Medicine, 7, 363-375.

Eden, D. (2002). Replication, Meta-Analysis, Scientific Progress and AMJ's Publication Policy. Academy of Management Journal, 45, 841-846.

Faul, F. \& Erdfelder, E. (1992). GPOWER: A priori, post hoc, and compromise power analyses for MS-DOS [Computer program]. Bonn University, Dept. of Psychology, Bonn.

Gelade, G.A. (2002). Creative Style, Personality, and Artistic Endeavor. Genetic, Social, and General Psychology Monographs, 128, 213234.

Graziano, W.G. \& Tobin, R.M. (2002). Agreableness: Dimension of Personality or Social Desirability Artifact? Journal of Personality, 70, 695-728.

Greenland, S., O'Rourke, K. (2001). On the bias produced by quality scores in meta-analysis, and a hierarchical view of proposed solutions. Biostatistics, 2, 463-471.

Hohn, M., Vârgă, D. \& Măruşter, L. (1999). Curs de statistică aplicată în ştiințe sociale. Volumul II, Timişoara: Tipografia Universității de Vest.

Hox, J.J. (1995) Applied Multilevel Analysis, Amsterdam: TT-Publikaties

Huffcutt, A.I. (2007). Research Perspectives on Meta-analyis. în Rogelberg, S.G. (coord.). Handbook of Research Methods in Industrial and Organizational Psychology. Blackwell Publishing House.

Hunter, J.E. \& Schmidt, F.L. (2000). Fixed Effects vs/ Random Effects Meta-Analysis Models: Implications for Cumulative Research Knowledge. International Journal of Selection and Assessment, 8, 275-292.

Hunter, J.E. \& Schmidt, F.L. (2004). Methods of Meta-Analysis. Correcting Error and Bias in Research Findings, Thousand Oaks: Sage Publishers.

Kelly, K.R. \& Pulver, C.A. (2003). Refining measurement of career indecision types: A validity study. Journal of Counseling and Development, 81, 445-454.

Kirk, R.E. (2005). The Importance of Effect Magnitude. În Davis, S.F. (coord.) Handbook of Research Methods in Experimental Psychology. Blackwell Publishing House.

Kwapil, T.R., Wrobel, M.J. \& Pope, C.A. (2002). The five-factor personality structure of dissociative experiences. Personality and Individual Differences, 32, 431-443.
Lievens, F., DeFruyt, F. \& VanDam, K. (2001). Assessors' use of personality traits in descriptions of assessment centre candidates: A five-factor model perspective. Journal of Occupational and Organizational Psychology, 74, 623-636.

Lipsey, M.W. \& Wilson, D.B. (2001). Practical Metaanalysis. Sage.

Lounsbury, J.W., Loveland, J.M. \& Gibson, L.W. (2003). An Investigation of Psychological Sense of Community in Relation to Big Five Personality Traits. Journal of Community Psychology, 31, 531-541.

Mak, A.S., Tran, C. (2001). Big five personality and cultural relocation factors in Vietnamese Australian student's intercultural social selfefficacy. International Journal of Intercultural Relations, 25, 181-201.

Maricuțoiu, L.P \& Sava, F.A. (2007). PowerStaTim 1.0 - Analiza puterii statistice şi a mărimii efectului. Disponibil la: www.psihologietm.ro începând cu data de 1.07.2008.

Meyer, T.D. (2002). The Hypomanic Personality Scale, the Big Five, and their relationship to depression and mania. Personality and Individual Differences, 32, 649-660.

Miclea, M. (1994). „Meta-analiza”. în Radu, I. (coord.). Metodologia cercetării şi analiza datelor, Cluj Napoca, p.309-334.

Mullen, B. (1989). Basic Advanced Meta-analysis. New Jersey: Lawrence Erlbaum.

O'Brien, T.B. \& DeLongis, A. (1996). The Interactional Context of Problem-Emotion, and Relationship-Focused Coping: The Role of the Big Five Personality Factors. Journal of Personality, 64, 775-813.

Penley, J.A. \& Tomaka, J. (2002). Associations among the Big Five, emotional responses, and coping with acute stress. Personality and Individual Differences, 32, 1215-1228.

Pitariu, H.D., Sulea, C., Zaborilă, C., Maricuțoiu, L.P. (2008). Justiție organizațională şi afectivitate negativă: o metaanaliză a relației acestora cu comportamentele contraproductive. Psihologia Resurselor Umane, 6, p.34-46.

Popa, R.I., Negoescu, L., Pleşea, S. \& Maricuțoiu, L.P. (2008). Personalitate şi leadership transformațional: o metaanaliză. Lucrare prezentată în cadrul Ediției a IV-a a Conferinței Naționale de Psihologie, Timişoara 23-25 mai 2008.

Robins, R.W., Fraley, R.C., Roberts, B.W. \& Trzesniewski, K.H. (2004). A Longitudinal Study of Personality Change in Young Adulthood. Journal of Personality, 69, 617640. 
Rose, C.L., Murphy, L.B., Byard, L. \& Nikzad, K. (2002). The Role of the Big Five Personality Factors in Vigilance Performance and Workload. European Journal of Personality, 16, 185-200.

Rosenthal, D.A., Hoyt, W.T., Ferrin, J.M., Miller, S. \& Cohen, N.D. (2006). Advanced Methods in Meta-Analytic Research: Applications and Implications for Rehabilitation Counseling Research. Rehabilitation Counseling Bulletin, 49, 243-246.

Rosenthal, R. \& DiMatteo, M.R. (2001). Metaanalysis: Recent Developments in QuantitativeMethods for Literature Reviews. Annual Review of Psychology, 52, 59-82.

Rusu, A., Macavei, B., Moldovan, R. \& Pintea, S. (2008). Încorporarea terapiei asistate pe animale în tratamentul psihoterapeutic al depresiei: investigație meta-analitică. Lucrare prezentată în cadrul Ediției a IV-a a Conferinței Naționale de Psihologie, Timişoara 23-25 mai 2008.

Sadowski, C.J. \& Cogburn, H.E. (1997). Need for Cognition in the Big-Five factor structure. Journal of Psychology, 131, 307-312.

Sava, F. (2004). Analiza datelor în cercetarea psihologică. Metode statistice complementare, Cluj Napoca: A.S.C.R.

Sava, F.A \& Maricuțoiu, L.P. (2007). PowerStaTim 1.0. - Manualul utilizatorului. Timişoara: Editura Universității de Vest.

Schmidt, F.L. \& Hunter, J.E. (2003). Meta-analysis. în Schinka, J.A.\& Velicer, W.F. (coord.) Handbook of Psychology. Volume 2: Research Methods in Psychology, New Jersey: John Wiley and Sons Inc.

Shafer, A.B. (2001). The Big Five and Sexuality Trait Terms as Predictors of Relationships and Sex. Journal of Research in Personality, 35, 313-338.

Spector, P.E., Fox, S., Penney, L. M., Bruusema, K., Goh, A. \& Kessler, S. (2006). The dimensionality of counterproductivity: Are all counterproductive behaviors created equal? Journal of Vocational Behavior, 68, 446-460.

Stan, A. (2002). Testul psihologic. Evoluție, construcție, aplicații. laşi: Polirom.

Thompson, R.L., Brossart, D.F., Carlozzi, A.F. \& Miville, M.L. (2002). Five-Factor Model (Big Five) Personality Traits and UniversalDiverse Orientation in Counselor Trainees. The Journal of Personality, 136, 561-572.

Thoms, P., Moore, K.S. \& Scott, K.S. (1996). The relationship between self-efficacy for participating in self-managed workgroups and the big five personality dimensions. Journal of Organizational Behavior, 17, 349-361.

Trip, S. (2006). Metaanalysis of rational emotive education studies with children and adolescents. Lucrare prezentată în cadrul Ediției a III-a a Conferinței Naționale de Psihologie, Cluj Napoca, 18-21 mai 2006.

Trull, T.J. \& Geary, D.C. (1997). Comparison of the Big Five Factor Structure Across Samples of Chinese and American Adults. Journal of Personality Assessment, 69, 324-341.

Tsaousis, I. \& Nikolaou, I.E.(2001). The Stability of the Five Factor Model of Personality in Personnel Selection and Assessment in Greece. International Journal of Selection and Assessment, 9, 290-301.

Tute, T.L. \& Bosnjak, M. (2001). Understanding differences in web usage: the role of need for cognition and the five factor model of personality. Social Behavior and Personality, 29, 391-398.

Urbina, S. (2004). Essential of Psychological Testing. New Jersey: Wiley.

Wilson, R.S., Mendes de Leon, C.F., Bienias, J.L., Evans, D.A. \& Bennett, D.A. (2004). Personality and Mortality in Old Age, The Journals of Gerontology, 59B, 110-116.

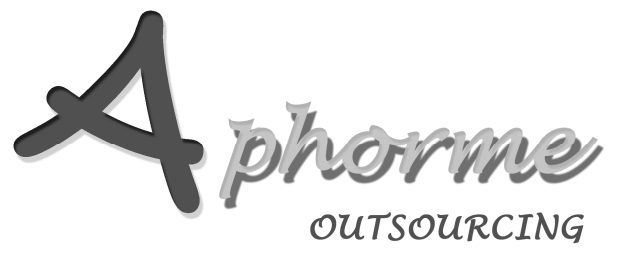

Organizational Diagnosis \& Development

Brand Research

Academic \& Institutional Evaluation

Organizational Simulation \& Gaming

Focus on people and opportunities.

For reliable outcomes

contact@aphorme.ro; www.aphorme.ro 